\title{
GENERALIZATIONS OF SPECIAL BIHARI TYPE INTEGRAL INEQUALITIES
}

\author{
LÁSZLÓ HORVÁTH
}

Abstract. In this paper we consider Bihari type integral inequalities in measure spaces. We give explicit bounds for the solutions under very weak conditions. The studied inequality essentially contains all inequalities of similar forms that was considered previously, the results and the proofs give a unified approach of the problem. The results are applied to establish the existence of a solution to the integral equation corresponding to the integral inequality.

Mathematics subject classification (2000): 26D15, 45G10.

Key words and phrases: Integral inequalities, measure spaces, abstract Lebesgue integral.

\section{REFERENCES}

[1] D. Bainov, P. Simeonov, Integral Inequalities and Applications, Kluwer Academic, Dordrecht (1992).

[2] I. BIHARI, A generalization of a lemma of Bellman and its application to uniqueness problems of differential equations, Acta Math. Acad. Sci. Hungar., 7, (1956), 81-94.

[3] S. G. Deo, M. G. Murdeshwar, A note on Gronwall's inequality, Bull. London Math. Soc., 3, 1 (1971), 34-36.

[4] L. HoRvÁth, Integral inequalities in measure spaces, J. Math. Anal. Appl., 231, (1999), 278-300.

[5] L. HoRVÁtH, On the associativity of the product of measure spaces, Acta Math. Hungar., 98, 4 (2003), 301-310.

[6] L. HoRVÁth, Integral equations in measure spaces, Integr. Equ. Oper. Theory, 45, (2003), 155-176.

[7] D. S. Mitrinović, J. E. PEČArić AND A. M. FInK, Inequalities Involving Functions and Their Integrals and Derivatives, Kluwer Academic, Dordrecht (1991).

[8] B. G. PACHPATtE, On a new inequality suggested by the study of a certain nonlinear convolution equation, An. Univ. din Timisoara, Seria Math., 32, (1994), 93-102.

[9] B. G. PACHPATte, A note on a certain inequality in the theory of differential equations, Octogon, 5 , (1977), 44-48.

[10] B. G. PACHPATTE, Inequalities for Differential and Integral Equations, Academic Press Limited, London (1998). 